\title{
Kimberlite as high-pressure melts: the determination of segregation depth from major element chemistry
}

Sweeney, R.J. and Winter, F.

Anglo-American Research Laboratories, PO Box 106, Crown Mines 2025, S. Africa

Kimberlites are volatile-rich, incompatible element-enriched ultramafic melts mixed with mantle material collected during ascent. Based on this, we adopt the view that small degree mantle melts of this style have to be in equilibrium with the olivine-dominated upper mantle. Furthermore, the fact that kimberlites most likely represent small degrees of melting (the volatile- and incompatible-element enriched character) they are also likely to have segregated from a mantle that retained garnet and clinopyroxene in the restite.

Herzberg (1992) proposed a method to determine the depth of magma segregation by recognizing that all near-solidus liquids should be in equilibrium with a peridotite containing garnet+clinopyroxene. To establish pressure of segregation, a variable may then be chosen which is affected by garnet+clinopyroxene melting only, such as $\mathrm{CaO} /\left(\mathrm{CaO}+\mathrm{Al}_{2} \mathrm{O}_{3}\right)$ ratio. Published experimental data permitted the definition of a locus of melts near the solidus (at garnet+clinopyroxene saturation) where the $\mathrm{CaO} /\left(\mathrm{CaO}+\mathrm{Al}_{2} \mathrm{O}_{3}\right)$ ratio is correlated with pressure (Fig. 1. from Herzberg, 1992, which has been updated here with more recent experimental data).

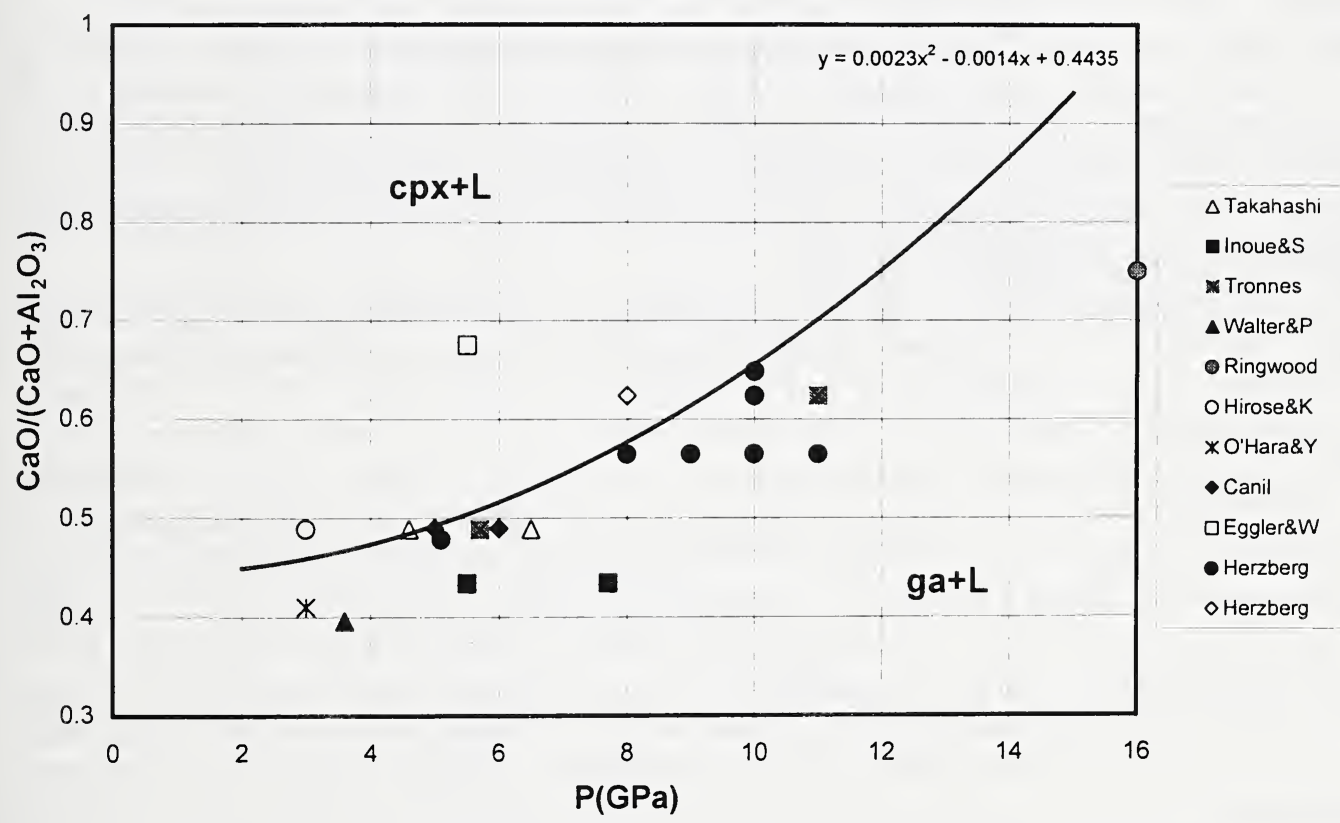

Fig. 1. $\mathrm{CaO} /\left(\mathrm{CaO}+\mathrm{Al}_{2} \mathrm{O}_{3}\right)$ (element-oxide data in $\mathrm{wt} \%$ ) of the liquid with experimental $\mathrm{P}$ (after Herzberg, 1992, Fig. 5) defining the locus of melt compositions where garnet (ga) and clinopyroxene (cpx) are liquidus phases. Points include experimental data from Herzberg (1992; solid circles and solid triangles), as well as other data not included in that study. Solid (black and grey) symbols are for melt compositions where garnet appears as the first $\mathrm{Ca}$-bearing phase and open symbols (including cross for O'Hara and Yoder, 1967) are for compositions where clinopyroxene is the Ca-Al phase closest to the liquidus. Data sources: Herzberg et al. (1990); Tronnes et al. (1992); Takahashi et al. (1993); Inoue and Sawamoto (1992), Canil (1991); Hirose and Kushiro (1993); Walter and Presnall (1994); Ringwood et al., (1992); O'Hara and Yoder (1967); Eggler and Wendlandt (1979). 
The two fields defined on Fig.1 depend on the pressure of the experiment, the $\mathrm{CaO} /\left(\mathrm{CaO}+\mathrm{Al}_{2} \mathrm{O}_{3}\right)$ ratio of the bulk composition and which $\mathrm{Ca}-\mathrm{Al}$ bearing phase (garnet or clinopyroxene) appears on the liquidus first (the order of crystallization is therefore important). The amount of crystallization of olivine and/or orthopyroxene will not affect the $\mathrm{Ca} / \mathrm{Al}$ ratio of the liquid composition. However, this ratio would be modified by crystallization of garnet and/or clinopyroxene, hence it is their first appearance that indicates the saturated condition.

Obviously the model requires that the temperature dependence of $\mathrm{Ca} / \mathrm{Al}$ exchange in the approximately $100^{\circ} \mathrm{C}$-wide garnet+clinopyroxene-melting interval is small. In addition, it is necessary that the clinopyroxene and garnet crystallized in the experiments in Fig. 1, have mantle compositions. The advantage of using the bulk composition in this manner is that liquid compositions in many near-solidus experiments are usually difficult to determine due to the small melt fractions involved. This is particularly problematic at pressures $>5 \mathrm{GPa}$ where melts are invariably subject to modification of their composition by quench crystallization. In addition the enhanced temperature gradients which exist in higher-pressure (multi-anvil) experiments may result in the analysis of liquids which are not in equilibrium with crystallized phases.

An assumption is that kimberlitic melts are saturated (residual phases) in both garnet and clinopyroxene. It may be argued that phlogopite may also be a residual phase in kimberlite melt production, which would affect the $\mathrm{CaO} /\left(\mathrm{CaO}+\mathrm{Al}_{2} \mathrm{O}_{3}\right)$ ratio significantly. Phlogopite (or any other K-bearing phase) may contribute toward the melt volume, but is clearly not residual (it melts out). This is evident from the fact that kimberlitic liquids at high pressure $(>3 \mathrm{GPa})$ are not saturated with (do not crystallize) phlogopite near their liquidus (e.g. Eggler and Wendlandt, 1979). Thus, the $\mathrm{CaO} /\left(\mathrm{CaO}+\mathrm{Al}_{2} \mathrm{O}_{3}\right)$ ratio in near-liquidus kimberlite melts will be controlled by the residual mineralogy: clinopyroxene and garnet only. A further assumption is that the wholerock major element data used are representative of a kimberlite liquid composition. The $\mathrm{P}$ sensitive ratio $\mathrm{CaO} /\left(\mathrm{CaO}+\mathrm{Al}_{2} \mathrm{O}_{3}\right)$ is plotted vs. $\mathrm{MgO} / \mathrm{SiO}_{2}$, which should also be pressure sensitive as an increase in pressure would contract the olivine phase field (and therefore olivine would be a greater contributor to the melt).

In kimberlites, olivine is the dominant liquidus phase throughout much of the pressure range (from field observations and experiments), and fractionation or addition (of xenocrysts) would cause arrays to spread to lower or higher $\mathrm{MgO} / \mathrm{SiO}_{2}$ ratios respectively with little change in $\mathrm{CaO} /\left(\mathrm{CaO}+\mathrm{Al}_{2} \mathrm{O}_{3}\right)$ ratio (Fig. 2). Consequently, $\mathrm{CaO} /\left(\mathrm{CaO}+\mathrm{Al}_{2} \mathrm{O}_{3}\right)$ would still be sensitive to depth of magma segregation, demonstrating that the positive correlation of $\mathrm{CaO} /\left(\mathrm{CaO}+\mathrm{Al}_{2} \mathrm{O}_{3}\right)$ vs. $\mathrm{MgO} / \mathrm{SiO}_{2}$ observed for a number of kimberlites is primarily determined by the pressure of melt-lherzolite equilibration. Examples of Group 1 and 2 kimberlites are included on Fig. 2. Characteristically, Group 1 data show a spectrum of segregation pressures within a single pipe. In contrast the Group 2 data, as a whole show the same spectrum but individual pipes have a more restricted pressure range in $\mathrm{CaO} /\left(\mathrm{CaO}+\mathrm{Al}_{2} \mathrm{O}_{3}\right)$ ratio and correlated (from Fig.1) pressure. For example, Bellsbank shows generally greater pressures of segregation than Sover and Finsch. The dispersion in $\mathrm{MgO} / \mathrm{SiO}_{2}$ ratios in Group 2 kimberlites is explained by olivine addition or fractionation.

One obvious conclusion to be made from Fig. 2 is that the high $\mathrm{MgO} / \mathrm{SiO}_{2}$ ratios of some samples can be explained only by the influence of a carbonate component. These melts have $\mathrm{MgO} / \mathrm{SiO}_{2}$ ratio's similar to olivine, but since $100 \%$ modal melting of olivine is unrealistic the involvement of a $\mathrm{Mg}$-carbonate component in kimberlite petrogenesis (i.e. dolomite or magnesite in the source) is suggested. In conclusion, it is stressed that the petrogenetic processes that are likely to dominate kimberlite evolution (i.e. the degree of crystallization or addition of olivine) act at a high angle to the positive correlation of $\mathrm{CaO} /\left(\mathrm{CaO}+\mathrm{Al}_{2} \mathrm{O}_{3}\right)$ and $\mathrm{MgO} / \mathrm{SiO}_{2}$ and this most likely preserves a pressure effect. Also plotted on Fig. 2 is the expected diamond/graphite transition pressure at a kimberlite liquidus temperature of $1500-1600^{\circ} \mathrm{C}$ and most kimberlite whole-rock data suggest segregation pressures greater than this: consistent with 


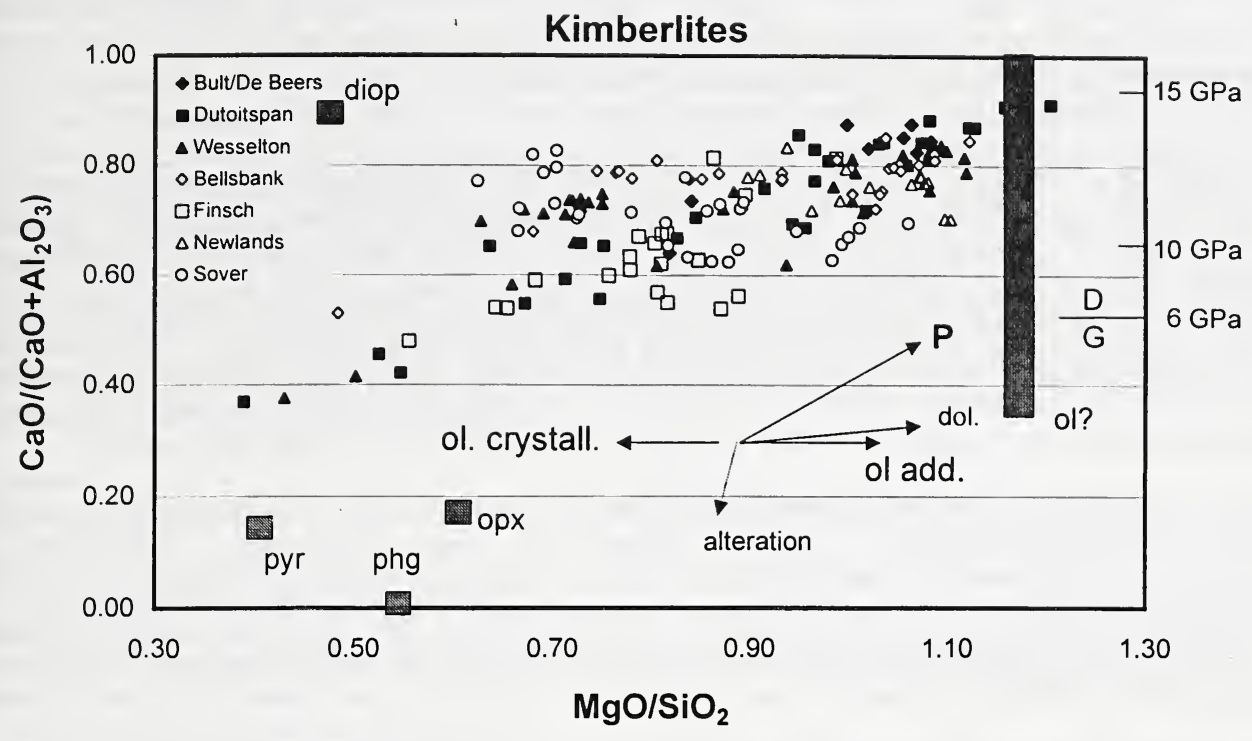

Fig. 2. Major element whole-rock geochemistry of selected kimberlites (element-oxide data in wt\%). Typical mantle mineral compositions are plotted as shaded rectangles (olivine, pyrope, orthopyroxene, diopside and phlogopite). The P-scale in GPa is from Fig. 1 and the $\mathrm{D} / \mathrm{G}$ (diamond-graphite) transition is for a kimberlite liquidus temperature $\left(1500-1600^{\circ} \mathrm{C}\right)$. Generalised vectors indicate the direction that various parameters would affect bulk composition: $\mathrm{P}$ pressure, carbonatite (dolomitic) addition to the source, olivine addition, increasing degree of olivine crystallization and alteration. Alteration would reduce the $\mathrm{MgO} / \mathrm{SiO}_{2}$ ratio, $\mathrm{Mg}$ is mobile and $\mathrm{Si}$ would be residual, and reduce the $\mathrm{CaO} /\left(\mathrm{CaO}+\mathrm{Al}_{2} \mathrm{O}_{3}\right)$ ratio, $\mathrm{Ca}$ is mobile and $\mathrm{Al}$ residual. To exclude effects of alteration and carbonatization the data have been screened to include samples where LOI $<15 \mathrm{wt} \%$ and $/$ or $\mathrm{CO}_{2}<10 \mathrm{wt} \%$.

\section{References}

Canil, D. (1991) Earth planet. Sci. Lett., 106, 64-72.

Eggler, D. and Wendlandt, R. (1979). Ext. Abs. $2^{\text {nd }}$ Int. Kimb Conf, 330-338.

Herzberg, C. (1992) J. Geophys. Res., 97 (B4), 4521-4540

Herzberg, C., Gasparik, T. and Sawamoto, H. (1990) J. Geophys Res., 95 (B10), 15779-15803

Hirose, K and Kushiro, I. (1993) Earth planet. Sci. Lett., 114, 477-489

Inoue, T. and Sawamoto, H. (1992) in: High P. Res (ed. Syono and Manghani), 323-331 (AGU, Washington DC). O'Hara, M.J. and Yoder, H.S (1967) Scott. J. Geology, 3, 67-117.

Ringwood, A.E., Kesson, S.E et al. (1992) Earth planet. Sci. Lett., 113, 521-538.

Takahashi E., et al. (1993) Phil. Trans. Roy. Soc. Lond., A 342, 105-120.

Tronnes, R.G., Canil, D. and Wei, K. (1992) Earth planet. Sci. Lett., 111, 241-255

Walter, M.J. and Presnall, D.C. (1994) J. Pet., 35, 329-359. 